Christos TEREZIS
Eirini ARTEMI*

\title{
ARETHAS OF CAESAREA AND ARISTOTELIAN STUDIES Study of case
}

Introduction. In this paper, we will try to present some points from the commentarial approach of the byzantine thinker Arethas of Caesarea ${ }^{1}$ in Aristotelian - logic mainly - treatise Categories ${ }^{2}$. The goal of our project is to highlight Arethas' of Caesarea scientific training and research capacity into

* Prof. dr Christos Terezis - Professor of the ancient Greek and Byzantine philosophy in the University of Patra; email: terezis@upatras.gr; dr Eirini Artemi - Theologist \& Classical Philologist, MA $\&$ Ph.D. of Theology of National and Capodistrian University of Athens; email: eartemi@theol.uoa.gr.

${ }^{1}$ Cf. J. Matula, Arethas of Caesarea, in: Encyclopedia of Medieval Philosophy. Philosophy between 500 and 1500, I, ed. H. Lagerlund, Heidelberg - London - New York 2011, 97-99: "Arethas, bishop of Caesarea, can be thought as the representative of the first Byzantine Renaissance and a major figure in the traditional period of Byzantine intellectual history in the ninth and tenth centuries. He commented on ancient philosophical works and recognized the importance of philosophical learning. He provided a transcription of a complete copy of Plato's works to which he added marginal notes. He is the author of a collection of scholia on Aristotle's texts. His importance as a student of Aristotle's works consists in his adoption of late Alexandrian Neoplatonism and his dependence on Porphyry's ontology. Arethas promoted encyclopedic curiosity and encouraged the copying of ancient manuscripts. Much of our knowledge of Greek antiquity is the direct result of his work. [...] He copied, commented, and lectured on the texts of Aristotle and Porphyry and played an important role in transmission of the philosophical traditions of antiquity in Byzantium. Apart from the preservation of the ancient texts, Arethas dealt with various philosophical issues as metaphysics and anthropology. He is usually viewed as a Platonizing thinker, mainly because of the considerable editing and his extensive scholia on the Platonic dialogues. From the philosophical point of view, Arethas revived interest in Byzantine thought. His attitude to Aristotle's work and logic is not very clear. He is a critic of Aristotle on doctrinal issues that are considered fundamental to Christian thought (the theory of soul, substance)". Additionally cf. Arethae archiepiscopi Caesariensis scripta minora, vol. 1, ed. L.G. Westerink, Leipzig 1968, 1-183, 186-294 and 296-340; Arethae archiepiscopi Caesariensis scripta minora, vol. 2, ed. L.G. Westerink, Leipzig 1972, 1-139; Arethas, Scholia in Aristotelis categorias, Arethas of Caesareas 's Scholia on Porphyry's Isagoge and Aristotle's Categories (Codex Vaticanus Urbinas Graecus 35), ed. M. Share, Corpus philosophorum Medii Aevi. Commentaria in Aristotelem Byzantina 1, Athens - Paris - Bruxelles 1994, 131-229; Arethas, Scholia in Porphyrii eisagogen, ed. M. Share: Arethas of Caesarea's Scholia on Porphyry's Isagoge and Aristotle's Categories (Codex Vaticanus Urbinas Graecus 35), Corpus philosophorum Medii Aevi. Commentaria in Aristotelem Byzantina 1, p. 1-130.

${ }^{2}$ Cf. Arethas Caesariensis, Scholia in Aristotelis categorias, ed. M. Share, Corpus philosopho- 
a particularly demanding text of Aristotle's Categories. This treatise permanently exposed multiple problems of interpretation in the relevant philosophical tradition. It can be observed that the commentary of Arethas does not expend itself in philological and explanatory comments. By this way, it reveals the expanded virtues of the byzantine hermeneutics, the main feature of which is the critical readings.

With his strict insistence, in a systematic method the Byzantine thinker presents a robust epistemological text which, in some cases, he renders as interpretative. Moreover, he utilizes the previous tradition (formed by e.g. Ammonium, Porphyrius, Simplicius, Elias, Olympiodoros, Philoponus, etc) and attempts - with great success indeed - to upgrade it into a complex theoretical system. We should also note that he doesn't manage this upgrade in the form of an adder circular infantilism. In order to corroborate his attempt, Arethas uses the method of descending or ascending joints, which is applied under the strict conditions of standard logic. Thus, he aims to deliver both general and specialized authorities, in every thematic part of his research and without departing from the actual theoretical orientations of the text that is being commented. We would notice that, from his point of view, the individual chapters of a treatise should follow both the general and specific principles that strictly accord with the content of each chapter.

We could extend our thought, noting that similar logical classifications could be found among various, in content, treatises such as Metaphysics and Categories. This is a detail that pervades the Aristotelian corpus. Despite their own specificities, these treatises have elements in common.

Through the aspect of general classification, our study is included in the research field that could be named "historical overview of the philosophical methodology". We assume that in a specific historical period, methodological issues, regarding a text in which he had filled his scientific proposals, have arisen with particular emphasis. Following that, we will present and evaluate the particular way of formulating that method which is selected for its approach. As criterion in this case, we will use the degree of the objective access of this method in a text that has concerned - and is still concerning - the philosophical interest.

The research question is as follows: which methodological rules does Arethas consider as necessary to illuminate the facts of this text? However, the question can be said in a different perspective: Does he try to integrate the Aristotelian text, based on the theoretical targeting of Byzantine philosophy? If that be the case, possible targeting of such an adaptation should not be unobserved from our research "suspicions". In this frame, our study also belongs

rum Medii Aevi. Commentaria in Aristotelem Byzantina 1, p. 131-229. The translation that is used is made by E. Artemi. 
in the field of history of philosophy ${ }^{3}$, which of course, besides analytical, it is also critical.

1. Towards a general epistemological aspects. From the beginning of his process, Arethas attempts to establish a coherent and completed system of objective principles on the well documented methodological approach of the Corpus of Aristotelian production. Thus, he contends, that it is necessary, in any relevant research analysis, to set six elements on examination. First, the "purpose", the element that sets the search for the reasons responsible to form the array of syllogisms in the particular treatise, be it general theoretical reasons of individual research. It is but a discussion considering the genetic terms that contributed to the emergence of this treatise.

"The purpose of the content of this treatise should be clarified, even if it seems to be clear from its title. The chapters of the treatise should be examined based on this title (The basic principle for Plato is the right definition of a subject that negotiated). Otherwise there is a great possibility that the content of the essay might be misunderstood"4.

And if we expand the above thoughts, we would comment that it should be taken into consideration that this essay analysis is part of a general theory or a general speculation that is underway or about to be established. With the above skills, the risk of researching errors, misinterpreting and unreasoning way of thinking are significantly reduced. At the same time the reason why this text has been composed with these chapters can be found. And the further advantage is that it can be objectively explained to what extent does the content respond to the general inscription title and in what manner. Certainly a posterior scholar could make an assessment for recapitalization or for chapter additions and removals.

Thus, by studying its content, it is necessary that we lead ourselves in answering questions, covering our knowledge gaps and developing our concerns and thoughts about the syllogisms of this treatise in a complete way. With these skills, we will broaden our theoretical horizons and will block our research diversions, due to the fact that we realize how considerations as arguments lead to conclusions. These conclusions contribute to overall targeting of the treatise in a definitive way.

${ }^{3}$ For the subject concerning platonism and aristotelism in Byzantium, cf. G. Podskalsky, Theologie und Philosophie in Byzanz, München 1977, 64-124.

${ }^{4}$ Arethas Caesariensis, Scholia in Aristotelis categorias, ed. Share, p. 131, 8-13 (the first number is the page in the critical edition, then verses of the work on that page). Indeed, Arethas notes that Aristotle's treatise On the soul declares its theoretical purpose with its inscription, but it is not observed in his treatises Prior Analytics (syllogistic logic) and Posterior Analytics (scientific method and syllogism). 
Secondly, the "usefulness", through which, readers seek to be adequately coordinated with the content of the treatise and its prolongations. Such coordination will provide the necessary equipment, both in theoretical and practical level.

"The «useful» thing, that is always asked, is to make the readers understand the content of the text. The method we should follow in order to write a treatise by reconstructing and making an argumentative essay, is different from the one used in a text written to mislead its readers"s.

By this criterion it is basically indicated that the composition of a treatise should be contributed to the prospect of a specialized - specific class - research discourse. In addition, with its support, we will avoid the arbitrariness of interpretation and we will understand both the structural syntax of the discourse and whether this certain treatise functions against an already formed theory whether in a reconditioning or complementary manner. To what extent does that contribute to the research development of this theory? The ability, also, to detect any deliberate or inadvertent deceptions from the pen of the author will be ensured.

This is an advanced dialectical penetration, a basic parameter for the assessment of the author. In any case, the ultimate objective refers to readers with regulatory conditions: to marginalize any false ways of his approach on this scientific essay, in order to harness and provide appropriate data for his personal maturation with respect to those which are included in this essay. To recognize himself as a researcher - even in a second level - and not remain in the state of simple and passive reader.

Third, the rank, namely the control of whether the subjects of discourse are classified in accordance to the likeness of content or, in other words, the immediate conceptual relevance:

"We don't have to search for rank of the dissimilar things (theories) in essence, because it is already known for example, logic comes first, morality second, physic third, mathematical fourth, and after all these theological follows. We should search for the rank of the similar things in essence whether the logic is similar to the logical, or the ethic to the morality etc." ${ }^{\prime}$.

This element indicates that the subject matter and methodological adequacy of a treatise clearly depends on the sequence of the chapters, on whether they obey to the principles of operational succession and transition logic, but within a general theory or science system having research section reports. If the

${ }^{5}$ Ibidem, ed. Share, p. 131, $14-132,1$. Arethas argues that the aristotelian treatises Topics and On Sophistical Refutations provide useful information to their readers for their theoretical directions.

${ }^{6}$ Ibidem, ed. Share, p. 132, 1-5. Arethas is significantly presented to know the tradition concerning the classification of the works of Aristotle. 
foregoing, which are in direct connection with the preceded, are complied the treatise has internal and validated explanations regarding its authorship.

First of all, this issue is placed within the discourse and the strictly relevant demarcations are examined, in the light of a critique referring to its syntactic structure. It is researched whether the discourse is characterized by unity of theme, a parameter which is a strict requirement for the subsequent ranking to a theoretical field. This is about the parameter that generally ensures common conceptual contours and united epistemological criteria throughout a text. This parameter has also theoretical accuracy claims. If the above are secured, the diversity of theoretical analysis and research discontinuities is sidelined, considered messy.

In each treatise, the single scientific objectives must be identified with a particular manifestation, resulting from the unwinding of the themes through individual stages. Or, in other terms, for what reasons it belongs, at least in its general research questions in a particular theoretical unity, and not in another one. We would underline that this section may be declared by the method which is used.

Fourth, the title. This parameter is crucial in terms of how the content of the concepts, that are included in the title of the treatise, is initially determined, in order to make clear what is going to follow in details. The inscription, in general, must hold the position of a summary or of the concise drafting the content of a long text.

"The title has to declare the whole purpose of the treatise. Indeed, the reader may be confused, if a noun such as Categories is used as a title. The term categories doesn't mean the offenses for trials, but the words which always have the role of a predicate and never the role of a subject"'.

The concepts are encountered by the reader with the title of a treatise; from the outset, they prepare him for the main directions of the research concerns of its author. Thus, their presence appears as mandatory, at least for the reader. We must, however add that this preparation fails adequately, but only to a prospective grade, a concept is likely to open, in principle at least, multiple sign and semantic nuances. Moreover, the strict unique content, that each time holds or assumes a meaning, depends oftentimes on the author of a treatise, who in the context of the evolution of the history of ideas - or and of tradition in which belongs to - comes close with the conceptual material of the past with new interpretative terms. The historical definition of concepts certainly works, more or less in a compulsory way, but the updates or the reconstructions should not be underrated. The above issue is adequately addressed by processing - the knowledge of the fifth item which follows.

${ }^{7}$ Ibidem, ed. Share, p. 132, 15-16. Arethas argues that the treatises Categories, On Interpretation and Topics declare their theoretical objective with the inscription. 
Fifth, the author. This is a parameter by which the authenticity of the discourse is controlled. It is a detail that safely guides us in whether we can integrate the discourse in the corpus of the total production of the person who presented himself as its writer. We should point out indicatively that most dialogues alleged being compiled by Plato, are the writing products of his students. "Only few are able to judge the trustworthiness of writers to examine critically the doctrines" ${ }^{\prime}$. In extension of this statement, the exclusion of falsified treatises is necessary in order to fully identify the unity of authorship of a researcher with strict literary or scholastic - and scholarly - criteria. The falsified text is inevitably determined by the posterior data and, whoever chooses this, attempts to introduce historic inconsistent in an already modulated corpus. It is underlined, however, that oftentimes we consider a text as theoretically reliable, solely because the person claimed to be its author is important. This risk should be avoided because it may have deliberately set the name of an illustrious writer - in order to upgrade a thesis with outside interventions or to the award with further honor and recognition the so-called writer. We would add, then, that the literary treatment of linguistic expressions is a key factor to guarantee the accurate identification of the author case by case.

Sixth is the division of discourse into chapters. This is a necessary identification as to theoretical specifications because it makes clear how and to what extent each chapter serves the formation - progress of the treatise as a single set. Through this detection, it will be possible to determine whether each chapter operates autonomously - a quite non possible version to a major extent - or if it is placed under the direction of a general section with broader objectives, which poses the terms of the content structure and its placement in a specific point rather to another certain one. Here reference is made in terms that are fundamental to set up a text with systematic theoretical claims:

"the division of a treatise in sections is desired as the east land. This division reveals its content to the readers and makes the meaning of the whole treatise clear"'.

The above division is part of the relationship "one-many", whilst a certain extent we could identify the relation "genus-species", too. In a treatise on particular research performance, the abundance of capital does not serve an extreme analytical scholasticism or merely a summation of meanings. It is a specification that exceeds the appositive recording information. It fits in presenting the details of a whole, which in theory is necessary and unavoidable.

\footnotetext{
${ }^{8}$ Ibidem, ed. Share, p. 132, 17-19. Also, Arethas says that he knows the relevant papers which dealt with the way of the adulteration of philosophical theories.

${ }^{9}$ Ibidem, ed. Share, p. 132, 19-26. Also, Arethas says that the order of chapters is useful, in order to have the researcher the prerequisites to study them, based on the meaning that they have or the role is played in the formation of a treatise.
} 
The respective theoretical aggregations arise by synthetic affinity individual reasoning - of which marked or discovered common ways - or are deployed by the manufacturing process through discrimination and analysis of those individual elements as section contains. With this structure, the cohesive way of evolution is revealed and the way the various successive build-up levels are interconnected, is identified. It is underlined that the above are vital importance much more when it comes to theories relating to applications and social practice, in the broad sense of the word. They clearly affect course of social life, which is surely influenced by mens' way of thinking, especially on an intellectual level. In every respect, however, a text such as Aristotelian Categories directs the person to choose the suitable mental ways and, by extension, to operate in a meaningful way in his social interventions.

2. At a meeting of realism with idealism. The second methodological principle of Arethas is related to the demand for specialized approaches and objective deepening in the content of each treatise analyzed in the overall structure. Being consistent with this principle, Arethas analyzes the Aristotelian logic treatise Categories, and sets as the first epistemological issue the detection of the literally accurate reference object. The approach that he seeks, relying on both historical and systematic method and characterized by the critical or even its reconditioning character. Apparently, the proposal for reformulation will be founded on general rules, that are justified according to their equivalence which has been strongly ratified, to the individual in every case research. Firstly, he doesn't accept the view of Alexander and Eustathius that the Categories consist exclusively one treatise on voices, i.e. on simple words or on external linguistic expressions with which the subject that is meant, describes what is subjected to remark:

"By the title Categories, some scholars believed that this essay had triple purpose. They made the exact mistake, as Alexander and Eustathius who supported that the name of the vocal sounds declares their purpose. (If the word vocal sound is synonym with speaking, the purpose of this word is profane)"10.

He does not accept, viz, the typical - conventional statement of the used terms. Subsequently, he rejects as univocal the position of Porphyrius that it is all about one single treatise on meanings.

More specifically, in an approach of the specific Aristotle work, based on epistemic criteria, the Neoplatonic philosopher - and the submmital exponent of the logical branching perceives the names as the reasonable designs which function as intermediate between the voices and things. At the same time, he considers they ensure the human consciousness on the knowledge of things. By this suggestion, the reference was made to inward word, which, according

${ }^{10}$ Ibidem, ed. Share, p. 133, 11-15. 
to the philosophical tradition, has two functions. According to the inherently voice version, it constitutes the conceptual armature of consciousness, while according to its assembly version, it constitutes the conceptual formulations and the way in which he reconstructs, in a theoretical way, the facts of the external reality, by using the deductive method. It is also noted that the already use of the pair signifier-signified is clear, but not, however, in conventional and superficial terms. The ontology however is not placed in the margin. Arethas' review - thought is founded primarily in determining whether those genera have logical or ontological content. It should be noted that in Christianity these genera have, first, ontologic and subsequently logical content.

"Porphyrius supports that we can obtain the knowledge of beings through their meanings, their vocal sounds and their same essence. So the species are in certain sense names of names"11.

Finally, Arethas expresses doubts towards Erlinous' view, according to which the Categories have strictly a pragmatic character and process only real beings, regardless of their meaningful yields and their language articulation. This specific commentator, having as base the linguistic material of the treatise, argued that the theoretical interest of Aristotle was addressed only to the description of objects of external reality. By this, he recognizes the Categories a clear, pragmatic orientation, in which the dominant role owns the object, or, with theoretical terms, the ontology. It is underlined, however, that such an aspect is clearly abstained from the targets of Stagiritis in whose treatises the epistemological element, as human attainment, was undeniable.

"Herminus contends that the thoughts, which expressions signify, are not the same among all people, since in equivocation it happens that the same form of expressions signifies more than one and he (Herminus) concludes that Aristotle never spoke of the same experiences and things, which would be expressed by the orthographically indistinguishable word tauta (these)"12.

In Arethas' assessment, Categories is not being referred to the voices only, because the negotiation of these verbal symbols is exclusively subject to the grammatical science. Also, nor to meanings, solely because the negotiation of these conceptual schemes, is subjected to the exclusive theoretical branch that deals with the soul. At this point, he obviously contemplates in a platonic manner and refers to Gnosiology, a complicated philosophical branch to its references and its processes. Finally, they do not only refer to objects, because the negotiation of sensory, these perceptual beings and causal conditions may belong exclusively within the competence of the first philosophy, which is metaphysics. The Byzantine thinker believes that these three disciplines are

\footnotetext{
${ }^{11}$ Ibidem, ed. Share, p. 133, 15-20.

${ }^{12}$ Ibidem.
} 
involved in the theoretical targeting of the treatise of Stagiritis. Moreover, we would note that no strand can be understood without the other two. Thus Aristotle's text is analyzed and interpreted in a complex prism and is considered to have three specific purposes, which are included in a more general one ${ }^{13}$. This is a very clear objective - and we dare to say synthetically dialectic approach because it excludes unambiguous visas and demonstrates the wealth of research - commentary possibilities and analyses an indeed demanding text. The analytic and the interpretative shape that is chosen by Arethas based on an epistemologic example, which includes all those research included factors: a) the external object as a result, b) its integration in theoretical schemes and c) its conceptual-linguistic mapping. Within a highly demanding cognitive precision, none of these three elements can have their own legitimacy, exclusive presence of such a degree that eliminates or expels the other two. Each of them is unable to establish a coherent theoretical proposal. Characterized by an all-round character and targeted direction, we need the addition of the rest two, which they will confer the full operation, the authentic purpose of his presence. Consequently, the approach of the Byzantine thinkers dialectical synthesis realism-idealism is obvious and every factor that partakes in an epistemological way maintains its responsibility and necessity for the understanding of this Aristotelian treatise to its whole. It could easily be argued that he defends the moderate-conceptual realism.

Alongside, Arethas argues that the Categories, by using their meaning performances, they register in the horizon of their petitions all beings, especially those that have the status of the existence and offer human consciousness the ability to establish all the logic and syllogistic figures. Hence, if the Categories haven't been composed, it would not be allowed - to any systematic researcher - the establishment of reasonable proposals, and by extension, neither argument nor evidence. Furthermore, the ineligible distinction between true and false or, respectively, between goods and evils would be rejected. The Categories therefore extend the human logical references to systematic scale and facilitate the formulation of merit discriminations, both epistemology and ethics, and lead each logical and acting man to the options that they correspond to him in order to express their creativity ${ }^{14}$. The subjects that this treatise develops, are displayed as the first cells and the primary springboards of thought of the process and theoretical assemblies; as well as, the foundations and conditions necessary to specify the logical structure of the dialectic between thinking and being. With their presence, the human consciousness

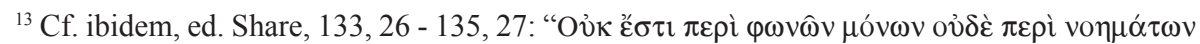

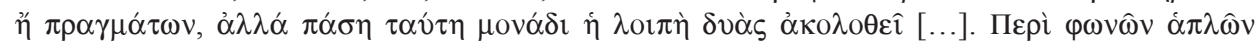

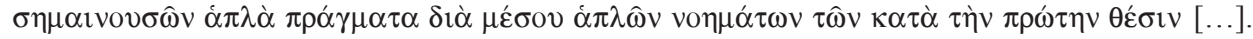

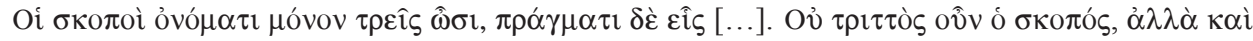

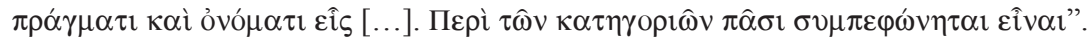

${ }^{14}$ Cf. ibidem, ed. Share, p. 135, 28 - 136, 6. 
acquires the skills necessary to integrate the external environment for mental combinations. What is of major importance, is to discover the internal rhythms of consciousness which govern or even the various interventions which experiences in whole or in part of it. Thus, in summary we would end up with the following sentence: The logic establishment and spread of consciousness is called to accurately reflect its operation of reality an achievement secured by reading the Categories.

3. To move beyond the initial questions. The third level, in which the systematic nature of Arethas' methodological approach means can be located, is the particular analytical way. By this manner, he puts the introductory questions or the early questions during the editing of an Aristotelian quotation. Thus, for example, he refers to the distinction of Stagiritis between the first and second essence, raises the following six questions in logical succession, which are equivalent to the specific ontological situations. Firstly, what was the reason that Aristotle began teaching first about the substance? It is a question concerning theoretical specifications and it does not only raise the question of logical priorities but and of ontologies.

The reflection is clearly targeting on whether the essence holds a hierarchical superior ontological level than the other categories, e.g. than the quality, which records particularities in each case. And therefore does it result from the contribution of the remaining categories or is it the precondition of their oversight. This is an issue that has occupied the platonic and the neoplatonic tradition by extending until the medieval thought. If we could examine Arethas' comments in a little daring way, we would raise the suspicion whether Arethas enters the thinking on possible dissolution of the substance or on limiting its sovereignty. It is however a potential which does not ensure the text of stable foundations.

Secondly, how many ways is the substance defined categorically and which is the substance that is referred? It is noted that this question is not mentioned in the ontological recommendation, on how the establishment of the substance is. The "how" generally cannot be independently from the "that" and the "because", since they were introduced one-dimensional research answers, under such an approach, exclusively on the way. If such an approach prevailed the existence or the establishment of the substance that should intertwine closely with the ingredients or the qualities who make it up and also with the Word and the ratio of the relevance. Such a version, however, clearly poses the potential for catalysis of the priority of the substance against the qualities. Then, the Byzantine thinker seeks the justification of the contextual reference which it is obviously selected by Aristotle, based on what is given or under the question that there are many essences. If we verge the question according to Christian doctrines we will assume that it is likely to suggest that the question is proposed to make distinguish between metaphysics and natural substance. Yet, there is a discrimination which for Arethas as Christian, is obvious. He it does 
not ensure strong support and justification in the Aristotelian texts that are examined here distinction will be encountered in Metaphysics of Stagiritis.

Third, for what cause Aristotle suggests the part of substance as first instead of the "whole" one as a second, though he is scientist? Here, it is thought as unconditional principle that scientists, as researchers of the general principles and laws of reality should situate the whole substance over the partial as an ontologically prior and superior. It is an expression of the famous controversy between realism and nominalism, having the first holding the primacies in the context of Christianity in the East. Even in such a context of priorities it is bound that Arethas would accept the catholic as causal or nucleus condition for the partial. His query is circumscribed on the basis that the above priority is not associated with methodological manner which Aristotle approximates his subject in this thematic unit. The norm should be the research thought to consider the whole as hierarchical condition of the partial, whether in the course starts from the opposite direction.

The gradual establishment of the whole must not lift its ontological priorities by the removal of any of the individual. However, in a subsequent paragraph Arethas notes that the Aristotelian writing, which he comments, it does not violate the ontological dependence - determinations. The direction of analysis, that Stagiritis selected, is raised merely on the fact that he addresses the issue of the acquirements of the logic analysis and synthesis, which he has accepted to tackle at its specific theme. And obviously, under this choice the logic will be linked to epistemology. At the same time, it will move under the conditions set by the goal of the teaching context in which his research has been put in a certain time ${ }^{15}$. This research has as basis the tangible fact, which is ensured by the individual (facts).

For this reason - and only within our baseline approach us - viz with the axiomatical position as a cause that the universal, as ontologically first and former, constitutes the possibility of the existence of partials must be detected, for what cause here it is characterized as a second. It will be indicated that the non-savvy reader would wonder concerning what Aristotle seeks to achieve. So, by generalization, we would note that it is necessary to be approached according to research - theoretical case in what way the ontological agent is concluded with the epistemic one and on which of the two is the theoretical priority attached.

Fourth: in what way is the substance genus and in what way do its species brook their articulation in a sharing of arrangement from which acquire their names? By this question it is attempted to be clarified whether the relation genus-species is being developed, within the meaning of proliferation - sharing of genus with specific stepwise programmed - and potentially hierarchical system. What does factor within this system contribute, subsequently, the

${ }^{15}$ Cf. ibidem, ed. Share, p. 169, 24 - 170, 37. 
name or categorical determinations to be assigned? Here, obviously, the reason and certainly ontological arrangement of individual realities is implied. These realities reflect upon the traditional Aristotelian shape on the depth and width of a concept. However, such a provision, viewed under conditionings of hierarchy, sets immediately as compulsory the distinguishment between the qualitatively superior and qualitatively inferior realities - partials or species.

However, the fact that the existence of the same substance as a leading source in a productive process, could lead us to the assessment that a caution and an ascending path are being committed, with the factor of division to be diffused. The first one will analyze qualifiedly, while the latter will lead to the substance itself, which will act as the supreme reality that the species - partials must be driven in order to recruit their exact function - names. The researcher, therefore, is invited to show the ontological conditions of a substance, and the parts of which it consists of, in order of operational priority, to deliver objectively what actually happens with the occurrence of this substance. He is invited to present, in a precise manner, the successions between the parties, in order to make understandable the coherence and operation of the whole.

Fifth, in what divisive way did Aristotle make a distinction in the essence as first and as second? Here, the criteria which they make feasible the distinction of the two substances were searched out. By using the strong hypothesis that this indicates the way the data held; is not together in a universal scale, only to some extent, ontologically relative ${ }^{16}$. This reflection includes for what cause the method of division is introduced, which necessarily involves two versions: whether it should detect differences between substances or that we are in a particular step of logic structure, in which the way of the discrimination among the previous and forward is visibly presented. Is it attempted by division to become the synagogue - coherent internal articulation of definitions, each of them will correspond to a particular category of similar beings? Should all in cases of material properties as peculiar ontological and logical layout? Such a provision clearly involves a taxonomic value, because with the differences that it underlines, it would go forward ranking - classification of substances, or furthermore and of the properties. By this way, it will be understandable for what reason the one substance is not included to another and they necessarily must be distinguished, without leading them to segregation or difference between them.

Sixth, whether the definition of the first substance is correct and adequate, as Aristotle states that it isn't in a subject or by a subject, so he does not specify what is it but what it is not. The query is based on the negative nature of the certain definition, which declares mainly nothing specific and hence on the reference plane and implementation of the object that it describes. It merely points out what should be avoided during our logical processes. It should be noted that

${ }^{16}$ We should note that the method of division has been studied particularly in the context of the Platonic tradition, notably in the dialogues Phaedrus, Politics and Sophistics. 
here Arethas raises the broader issue of apophasis, stressing that the categorical determinations cannot be attributed either in inexistent or in divine ${ }^{17}$.

In a broader view of the issue, this means that the definition is the demarcation, the clarity and the record of all the elements which constitute the identity of a being unity and diversity to all the others. Initially, all these elements are not at least obvious to the thematic development of the Categories, but however this leads to the conclusion that Aristotle is not methodical to his labelling. In the Metaphysics and in the Posterior Analytics, for example he addresses this topic from a different point of view.

According to our paper, we have reached to the following three conclusions:

a) By imparting a particularly significant question concerning the method, Arethas makes clear that he incorporate his approaches to a strict framework of rules - incipiencies. His method is structured in three levels and is supported strictly to subjects' property, which are researched. The persistence in this method emerges him as an objective commentator. He carries out his voluntary restraints during the presentation of the Aristotelian text. This is the result of his applying positions which are internally justified and inviolable to the specific purpose that they serve. We would take place, then, that the way which a text is approached, is moving from external to internal conditions of the method and from general to specialized authorities. By this way, it gives prominence to a well-established example, in the context of which the known object is examined in such a way as to exclude the arbitrariness of the knowing subject.

b) The Byzantine thinker argues a systematic outline of the analytical method. Whether he raises general methodological authorities or specialized, seeking to discover and process the simplest elements of which an Aristotelian text is constituted. Nothing is taken as self-evident. So in the beginning he sets such questions in each case, through which he attempts to capture source of deposit and view all concepts and reasoning.

c) In the goals of Arethas, there is the use and as much as possible the development of the interpretive methods. Although he analyzes a treatise

${ }^{17}$ Cf. Arethas Caesariensis, Scholia in Aristotelis categorias, ed. Share, p. 168, 1-2: “๕̌ $\xi \alpha \hat{\mathrm{v}-}$

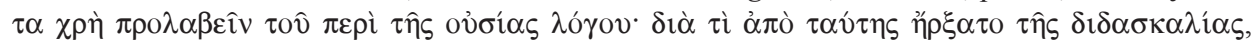

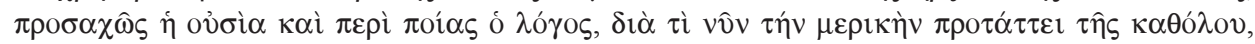

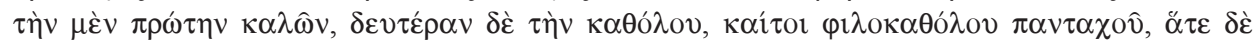

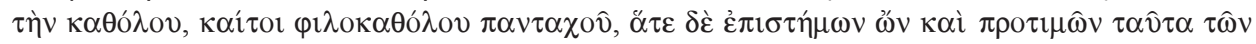

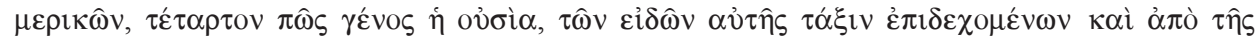

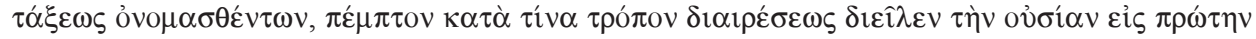

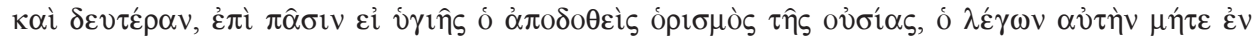

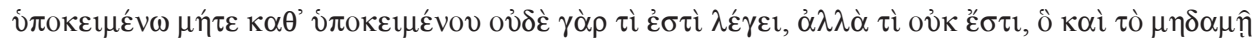

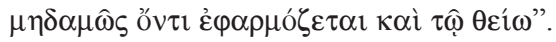


especially known and systematically processed by the philosophical tradition - which is presented somehow as unknown - he attempts to approach it with a new way. His research movement is original, since he does not simply use the historical and systematic method, but he raised them within their synthetic reciprocity. Essentially he attempts a positivistic hermeneutic approach to the text, which would be characterized as positivist, since without derogations; he reduces its content to the conditions by which it is founded.

Building on the three above elements, we could say that Arethas is one important stage of the movement of Aristotelianism in the Byzantine Empire, and even in the moment that he is simultaneously an important Platonist thinker. Thus, in his objectives he has to draw a correct argument, which, through the utilization of various philosophical traditions, would lead him constantly to procedures in proving with a claim of completeness and, therefore, the valid quest for certainty.

\section{ARETAS Z CEZAREI I STUDIA NAD ARYSTOTELESEM. STUDIUM ZAGADNIENIA}

\section{(Streszczenie)}

Artykuł przybliża postać bizantyjskiego myśliciela, przedstawiciela renesansu bizantyjskiego, żyjącego w X w., biskupa Aretasa z Cezarei, oraz jego komentarz do Kategorii Arystotelesa. Celem jest ukazanie naukowego warsztatu i badawczej pasji, jaką odznaczał się biskup Aretas w komentowaniu szczególnie wymagającego tekstu, jakim są Arystotelesowskie Kategorie, oraz przedstawienie zasad bizantyńskiej hermeneutyki tekstów filozoficznych, której główną cechą jest krytycyzm oraz unikanie filologicznych i objaśniających komentarzy. Scholia Aretasa do Arystotelesa pokazują, że biskup Cezarei używał tekstu filozofa przede wszystkim do wykładania na jego podstawie neoplatońskiej ontologii.

Key words: Arethas of Caesarea, Aristotle's Categories, apophasis, realism, platonic and neoplatonic tradition.

Slowa kluczowe: Aretas z Cezarei, Kategorie Arystotelesa, realizm, tradycja platońska i neoplatońska.

\section{BIBLIOGRAPHY}

\section{Sources}

Arethas of Caesarea, Scholia in Aristotelis categorias, in: Corpus philosophorum Medii Aevi. Commentaria in Aristotelem Byzantina 1, ed. M. Share, Athens - Paris Bruxelles 1994, 131-229. 


\section{Literature}

Anton J.P., Neoplatonic elements in Arethas'Scholia on Aristotle and Porphyry, in: Néoplatomisme et Philosophie Médiéval. Actes du Colloque international, Société International pour l'étude de la Philosophie Médiéval, ed. I.G. Benakis, Turnhout 1997, 291-306.

Encyclopedia of Medieval Philosophy. Philosophy between 500 and 1500, I, ed. H. Lagerlund, Heidelberg - London - New York 2011.

IERodiakonou K., The Byzantine reception of Aristotle's categories, "Synthesis Philosophica" 39 (2005) 7-31.

Kotzia-Panteli P., On Arethas of Caesarea's Scholia on Porphyry's Isagoge and Aristotle's Categories, "Hellenica" 46 (1996) 396-410.

Podskalsky G., Theologie und Philosophie in Byzanz, München 1977.

Terezis CH., The theological knowledge of the orthodox East [in Greek], Athens 1993.

Terezis CH., Philosophical Anthropology in Byzantium [in Greek], Athens 1993.

TEREZIS CH., The position of the greek philosophy in the orthodox East [in Greek], Thessaloniki 1995. 
